\title{
State educational policy through the prism of modern processes in the field of knowledge reproduction
}

\author{
Natalia Hrabovenko, Interregional Academy of Personnel Management
}

The article analyzes the modern state educational policy. It is emphasized that the main tasks for the Ukrainian state are to determine social, economic, global and other factors that have both positive and negative impact on the formation of state educational policy, on the model of building educational policy capable of solving current global problems of humankind. It is emphasized that the conceptual analysis of the possibilities of solving global educational problems should be considered in the historical aspect of this issue, which will provide an opportunity to obtain methodologically comprehensive results.

It is emphasized that the dialectical, phenomenological, structural-functional method, the method of collecting and analyzing the original empirical material, content analysis of documents, the method of building temporal models of systems development should be used as basic methods of research of state educational policy. A brief description of the seven stages of the evolution of educational policy concepts and their relationship with the process of reproduction and accumulation of knowledge is given. The evolution of personal and public interests in educational policy is summarized by building temporal spatial models, analyzes a number of global educational problems faced by each nation state in the XXI century, identifies the unique role of balanced state educational policy in preventing threats to the reproduction of scientific knowledge. The principles of realization of the national educational policy are defined: establishment of cooperation of consumers and creators of innovative technologies; breakthrough in the creation and application of information and communication technologies; unification of the global educational space; prevention of increasing the digital divide; elimination of personnel donations of individual countries; establishing flexibility in co-financing education; continuing education. It is established that the implementation of all formulated ethos in the national educational policy will provide an effective result of the functioning of the educational sector, in accordance with the demands of the XXI century, and will protect from current threats in the field of knowledge reproduction.

Keywords: state educational policy, marketing of education, internationalization of education, information and communication technologies in education, education reform, continuing education, model of educational policy construction

\section{Державна освітня політика крізь призму сучасних процесів у сфері відтворення знань}

\section{Наталія Грабовенко, Міжрегіональна Академія управління персоналом}

У статті аналізується сучасна державна освітня політика. Підкреслюється, що головними завданнями української держави $є$ визначення соціальних, економічних, глобальних та інших факторів, які завдають як позитивний, так і негативний вплив на формування державної освітньої політики, на модель побудови освітньої політики, здатну вирішувати поточні глобальні проблеми людства. Підкреслюється, що концептуальний аналіз можливостей вирішення глобальних освітніх проблем слід розглядати в історичному аспекті цього питання, що дасть можливість отримати методологічно комплексні результати.

Підкреслюється, що діалектичний, феноменологічний, структурно-функціональний метод, метод збору і аналізу вихідного емпіричного матеріалу, контент-аналіз документів, метод побудови темпоральних моделей розвитку систем слід використовувати в якості базових методів дослідження державної освітньої політики. Наведено короткий опис семи етапів еволюції концепцій освітньої політики та їх взаємозв'язку з процесом відтворення і накопичення знань. Визначено, що еволюція особистісних і суспільних інтересів в освітній політиці узагальнюється шляхом побудови тимчасових просторових моделей, наведено аналіз низки глобальних освітніх проблем, 3 якими стикається кожна національна держава в XXI столітті, визначається унікальна роль збалансованої державної освітньої політики в запобіганні загроз відтворення наукових знань. Визначено принципи реалізації національної освітньої політики, а саме: налагодження співпраці споживачів та творців 
інноваційних технологій; прорив у створенні і застосуванні інформаційно-комунікаційних технологій; об'єднання світового освітнього простору; запобігання збільшенню цифрового розриву; ліквідація кадрового донорства окремих країн; забезпечення гнучкості в співфінансуванні освіти; безперервна освіта. Встановлено, що реалізація всіх сформульованих етосів у національній освітній політиці забезпечить ефективний результат функціонування освітньої сектора відповідно до вимог XXI століття і захистить від поточних загроз в сфері відтворення знань.

Ключові слова: державна освітня політика, маркетинг освіти, інтернаціоналізація освіти, інформачійно-комунікачійні технології в освіті, реформування освіти, безперервна освіта, модель побудови освітньої політики

\section{Государственная образовательная политика через призму современных процессов в области воспроизведения знаний}

\section{Наталья Грабовенко, Межрегиональная Академия управления персоналом}

В статье анализируется современная государственная образовательная политика. Подчеркивается, что главными задачами украинского государства являются определение социальных, экономических, глобальных и других факторов, которые оказывают как положительное, так и отрицательное влияние на формирование государственной образовательной политики, на модель построения образовательной политики, способную решать текущие глобальные проблемы человечества. Подчеркивается, что концептуальный анализ возможностей решения глобальных образовательных проблем следует рассматривать в историческом аспекте этого вопроса, что даст возможность получить методологически комплексные результаты.

Подчеркивается, что диалектический, феноменологический, структурно-функциональный метод, метод сбора и анализа исходного эмпирического материала, контент-анализ документов, методпостроения темпоральных моделей развития систем следует использовать в качестве базовых методов исследования государственной образовательной политики. Дано краткое описание семи этапов эволюции концепций образовательной политики и их взаимосвязи с процессом воспроизводства и накопления знаний. Определено, что эволюция личных и общественных интересов в образовательной политике обобщается путем построения временных пространственных моделей, дан анализ ряда глобальных образовательных проблем, с которыми сталкивается каждое национальное государство в XXI веке, определяется уникальная роль сбалансированной государственной образовательной политики в предотвращении угроз воспроизводства научных знаний. Определены принципы реализации национальной образовательной политики: налаживание сотрудничества потребителей и создателей инновационных технологий; прорыв в создании и применении информационных и коммуникационных технологий; объединение мирового образовательного пространства; предотвращение увеличения цифрового разрыва; ликвидация кадрового донорства отдельных стран; обеспечение гибкости в софинансировании образования; непрерывное образование. Установлено, что реализация всех сформулированных этосов в национальной образовательной политике обеспечит эффективный результат функционирования образовательного сектора в соответствии с требованиями XXI века и защитит от текущих угроз в области воспроизводства знаний.

Ключевые слова: государственная образовательная политика, маркетинг образования, интернационализация образования, информационные и коммуникационные технологии в образовании, реформирование образования, непрерывное образование, модель построения образовательной политики

\section{Introduction.}

The creation and wise usage of new scientific knowledge is becoming the main weapon for all national economies in the struggle for survival in a globalized world.

The state of the educational system builds a fundament for the progressive development of society; the level of providing the population with quality education produces the competitiveness of national science and outlines the possibilities for the development of all spheres of social coexistence. Adjusting the vectors of effective cooperation between the various actors in the education system, have a direct or indirect 
impact on the development of the education sector or seek to realize their interests in this development, is the main area of functioning of educational policy mechanisms. In a globalized world, with the emergence of potential threats to the processes of reproduction of knowledge, it becomes necessary to constantly assess the effectiveness of educational policy and to balance state vectors of development.

The analysis of social, economic, global and other factors that influence the formation of state educational policy, the model of building educational policy that can solve current global problems of humankind, became the main objects of the study. Conceptual analysis of the possibilities of solving global educational problems through the mechanisms of educational policy is heuristically significant and cognitively valuable; consideration of the historical aspect of this issue makes it possible to obtain methodologically comprehensive results.

Results. The methodological fundament of the study includes the dialectical, phenomenological, structural-functional method, the method of collecting and analyzing the original empirical material, the content analysis of documents, the method of constructing temporal models of systems development, and others.

The formation of modern ideas about educational policy began in the 50 s of the twentieth century. With each new decade, there have been significant paradigm shifts in the methodology of educational research, which «have contributed to the consistent improvement of tools and skills in policy interpretation, given the growing awareness of the complexity of education and policy issues»». (Aviram, 1996. p. 437)

The evolution of educational policy concepts and their relationship with the process of reproduction and accumulation of knowledge during the study is summarized in the following stages:

1. The stage of step-planning educational policy (1950s). Educational and political thought is subject to the needs of educational planning. "Not quality but quantity" - the emphasis on providing as many people as possible with the existing level of education suited the producers of educational policy. The world community has tried to bridge the growing gap between the 18 literate and illiterate populations in a situation of progressive growth in the amount of scientific knowledge.

2. The stage of reciprocity of education with economic and political sphere (the first half of the 1960's). The educational system is regarded in the open space of the relationship of the educational field subjects with society and national economy. The social mechanism of transformation of social interests into educational policy remains etatic.

3. The stage of educational policy objectification (the second half of the 1960s)

The state retains the position of a monopoly manager of available resources, reserves the right to be the sole representative and provider of public interests in education. Educational research seeks to enrich educational policy makers with valuable information to make their activities more productive.

4. The stage of applied educational policy analysis (1970's)

The self-regulated market and the customer of educational services (individual or legal entity, enterprise, civil society institutions) begin to dictate the rules in the field of education. Scientific opinions about the inability of educational policy makers to produce objective and far-sighted plans for the development of the education sector under the pressure of etatism are substantiated. The concept of the number of educational services is gradually shifting to their quality.

5. The stage of education marketization (1980's)

The problem of the dichotomy of state regulation and systemic and institutional autonomy of education is researched. The analysis of national education systems in the coordinate system of the balance of state and market control is becoming widespread. A significant indicator of market control of education characterized competitive educational systems with a high degree of knowledge and innovation of educational and scientific services. A significant indicator of state control characterized accessible education with a traditional teaching methodology, but one that did not fully focus on global trends in the development of scientific knowledge. 


\section{Stage of strategic educational policy (1990's)}

In the context of a growing shortage of resources, strategic approaches to the development of educational policy have become relevant. This stage is characterized by the growing influence on educational policy of the claims of certain stakeholders, in particular civil society institutions, non-profit organizations. The current increase in the prestige of certain professions that are in demand abroad, rather than nationally, through aggressive advertising in a particular country, may introduce some imbalance into this axis.

7. Stage of institutionalization of the educational market and the formation of a global educational space (the beginning of the XXI century)

There are growing personal requests to the network of educational services and educational policy in general - a person, taking into account the requirements of the information society, in their own effective professional development seek to meet their needs in the form of quality, affordable, relevant, competitive and innovative education.

Summarizing the growing anthropological motives in the works of foreign theorists of educational policy, in the course of the study it was decided to determine the personal aspect of the basic in the construction of the temporal scheme of educational space at this stage. The formation of personal educational needs begins to be influenced by other players in the educational field. In the course of the research, we determined that for an effective educational policy, all actors (state, market, civil society institutions, interested business structures and national educational staff) must be balanced in their influence on the individual, who is searching for the place to implement educational needs. If the pressure of any of them causes disparities, the educational demands of the individual will remain unsatisfied or will be incompletely satisfied (for example, high-quality education is not always available to the general population; education relevant in this society does not always contain an element of innovation). At this stage, in the absence of a stable, orderly relationship between the institute of education and the institute of the market, training began not on the basis of market needs, but on the demand for educational services, which often gives false signals. While putting personal educational requests in the center of state educational policy, it is necessary to consciously consider the vector of the latter, so as not to succumb to the hype of social order, and adequately respond to the state of employment. The study found that the state has a significant influence on the production of quality and affordable education, educational staff influences the quality and innovative content of education; and market has effect on innovation and competitiveness of the educational service system, etc.

In our opinion, in order to balance the conscious and adequate XXI century personal educational needs and overcoming or preventing threats to the reproduction of scientific knowledge in the information society, all vectors of national educational policies should be aimed at implementing such principles.

1) Established cooperation between consumers and creators of innovative technologies.

In our opinion, in the modern economy, educational institutions perform the function of enriching the individual only with professional knowledge. The XXI century demands the education of a creative and independent, mobile and comprehensively developed personality, able to respond flexibly to the changing conditions of the information society. In a knowledge-based society, public education policy, by defining the rules of the game in the educational space, should promote the implementation of developmental research programs that will teach people, above all, to develop new knowledge.

2) A breakthrough in the creation and application of information and communication technologies (ICT).

This idea includes the development and implementation of innovative multimedia programs, virtual courses of lectures and libraries, forms of distance learning. The largest US universities have been operating in parallel for a decade in a new dimension of «electronic universities» (UNESCO World Report, 2005, p.84-85). This experience will be useful for every national education system. However, it should be remembered that ICT is only a tool for the development of cognitive abilities of the 
individual, which should be used wisely. After all, information is a passive object of subjective interpretation, and knowledge is intensive. It is essential to have some social experience while learning.

3) Unification of the global educational field. In educational practice, there are known examples of unsuccessful usage of imported educational technologies due to the lack of adequate social capital on a national basis, even in the presence of a highly developed education system. In the process of forming a single educational space, it is the responsibility of educational policy makers to properly rethink international educational experience. In this sense, overcoming the difference between educational standards by states through the definition of universal standards of one of the countries, as a consequence of the practice of creating an international center for standardization and examination of education systems, will contribute to the development of a united educational field.

4) Preventing the increase of the digital dividing. There is a direct link between the state of the information society and the formation of the digital dividing, which, according to experts in the world, is constantly growing, primarily due to illiteracy. The essence of the digital dividing is not in quantitative parameters, but in the real provision of GDP growth through a knowledge-based economy. Therefore, public strategies at the national level of partnership between educational institutions and the population should work to prevent the widening of this gap.

5) Liquidation of personnel donations of individual countries. A significant role in the recruitment of scientific and teaching staff of the highest qualification in developed countries assigned to the mobility of scientists and the migration of highly qualified specialists. The United States currently employs 400,000 people with higher education from Europe, and only $13 \%$ of them plan to return home. (Time Europe) Thus, European countries, where educational services are mostly paid for by the state, become educational donors to the United States. The donor state prepares a specialist at the expense of the national budget and, at the same time, loses them, being unable to provide good work. 20
At the same time, in the era of the formation of the global educational field, the migration of scientists should be encouraged. Therefore, certain strategic programs for the exchange of resources between the donor country and the host country should be considered at the interstate level, through the mechanisms of national educational policies.

6) Establishing flexibility in the education co-financing. There is no doubt that the modern type university was created by Europe before America appeared on the map. At this stage, Europe has lost its leadership in higher education to the United States (according to the Shanghai ranking, the United States has 17 universities in the top twenty world universities-leaders) (Time Europe). The reason for this phenomenon is the well-established co-financing of education in the United States, which comes from various sources: from the state, from philanthropists, entrepreneurs and, of course, the students themselves. Limited public funding for European universities means that European governments are forcing universities to teach more and more students without the necessary funds. The quality of education is inevitably declining. Although, as the American model shows, people are willing to pay for quality higher education because they know it will benefit them in the future. That is why America spends twice as much GDP as Europe on higher education.

Detailed state regulation of education limits the ability of universities to respond quickly to changing environments. As more countries move to co-financing, public education policy should aim to help talented students, but focus on establishing non-state channels of education funding.

7) Continuous education. Declining birth rates and increasing life expectancy are the factors that increase the need for continuous education. According to forecasts, by 2050 the working age population of Europe will decrease by $19 \%$ compared to 2008 , and the number of people over 65 will increase by $60 \%$. As a result, in Europe, the average ratio between pensioners and the working population will increase from $24 \%$ in 2008 to $50 \%$ in 2050 . The result of such growth will be an increase in the burden on pension funds, 
rising health care costs while reducing the number of workers producing material goods. In this sense, the changing demographic situation will require additional investment in technology and human capital to ensure that the renewal of knowledge occurs not only through young people but also through people of all ages.

Conclusion. Thus, the study summarizes the evolution of personal and public interests in educational policy through the construction of temporal spatial models, analyzes a number of global educational problems faced by each state in the XXI century, identifies the exceptional role of a balanced state educational policy in the process of preventing threats to the reproduction of scientific knowledge. It is established that the implementation of all formulated educational ethos in the national educational policy will give an effective result of the functioning of the educational sector, in accordance with the demands of the XXI century, and will protect from current threats in the field of knowledge reproduction.

In the process of forming the model of public administration in modern Ukraine, in addition to the above, it is likely to take into account the innovative aspect (it mainly affects the quality of education to manage it) and the regional factor of education. All European countries are now more interested in controlling the quality and development of higher education through the organization of effective governance in higher education institutions, gradually expanding their autonomy and responsibility. In practice, this is reflected in the creation and development of structures that perform intermediary functions between the state and higher education institutions. Data on the level and quality of education play an increasing role in investment decisions. The multi-subject educational policy of the XXI century encourages a new consideration of the education phenomenon in the context of the need to prevent global educational problems that can lead to information catastrophes and hinder the formation of a united educational field. Openness of interaction between the state and other subjects of educational and political relations can prevent threats to the reproduction of knowledge with the assistance of national educational policies. In a globalized world, with the emergence of potential threats to the processes of reproduction of knowledge, it becomes necessary to constantly assess the effectiveness of educational policy and balancing state vectors of development.

\section{REFERENCES}

Aviram, A. (1996). The Decline of the Modern Paradigm in Education. International Review of Education, 42 (5), 437-438.

Bykov, V.Yu. (2001). Intehratsiia systemy osvity Ukrainy u svitovyi osvitnii prostir: proektnyi pidkhid yak efektyvnyi instrument yii realizatsii [Integration of the education system of Ukraine into the world educational space: project approach as an effective tool for its implementation]. Profesiina osvita: pedahohika i psykholohiia - Vocational education: pedagogy and psychology, 3, 65-73 [in Ukrainian].

Reimers, F., \& McJinn, N. (1997). Informed Dialogue - Using Research to Shape Education Policy around the World. Westpost. Praeger.

Semenets-Orlova I. (2019). Processual aspects of educational changes: empirical findings institutional level Advanced Education, 1(7), 64-67. doi: 10.20535/2410-8286.82887.

Semenets-Orlova, I. (2018). Tendencies in reforming the educational system of modern Ukraine: national and regional aspects. Public management : collection, 2 (12), 171-179. doi: 10.31618/vadnd.v1i12.91.

Semenets-Orlova, I.A. (2018). Teoretychni zasady derzhavnoho upravlinnia osvitnimy zminamy v Ukraini [Theoretical principles of public administration of educational changes in Ukraine]. Extended abstract of Doctor's thesis. Kyiv: Mizhrehion. Akad. upr. personalom [in Ukrainian].

Shevchenko, S. O. (2012). Obgruntuvannia kontseptsii efektyvnoho derzhavno-hromadskoho mekhanizmu upravlinnia yakistiu vyshchoi osvity v Ukraini [Substantiation of the concept of effective state-public mechanism of quality management of higher education in Ukraine]. Publichne administruvannia: teoriia ta praktyka-Public administration: theory and practice, 2. Retrieved from http://nbuv.gov.ua/UJRN/Patp_2012_2_17 [in Ukrainian]. 
Standarty i rekomendatsii shchodo zabezpechennia yakosti v Yevropeiskomu prostori vyshchoi osvity (ESG) [Standards and Guidelines for Quality Assurance in the European Higher Education Area (ESG)]. (2015). Kyiv: TOV “TsS". Retrieved from http://www.britishcouncil.org.ua/sites/default/files/standards-and-guidelines_for_qa_in_the_ehea_2015.pdf [in Ukrainian].

Time Europe. Retrieved from http://www.time.com/time/europe/magazine/printout/0,13155,901040119-574849,00.html.

UNESCO World Report. (2005). Towards Knowledge Societies. Paris.

\section{Грабовенко Наталія}

Кандидат педагогічних наук, доцент

Міжрегіональна Академія управління персоналом

\section{Hrabovenko Natalia}

Candidate of Pedagogic Sciences, Assoc. Prof. Interregional Academy of Personnel Management

Email: natagrabovenko@ukr.net

ORCID: 0000-0001-8896-1292

Цитування: Грабовенко, Н. (2020). Державна освітня політика крізь призму сучасних процесів у сфері відтворення знань. Аспекти публічного управління, 8(5), $16-22$. doi: $10.15421 / 1520101$

Citation: Hrabovenko, N. (2020). Derzhavna osvitnia polityka kriz pryzmu suchasnykh protsesiv u sferi vidtvorennia znan [State educational policy through the prism of modern processes in the field of knowledge reproduction]. Public administration aspects, 8(6), 16-22. doi: 10.15421/1520101 